\title{
Late Quaternary eruption of the Ranau Caldera and new geological slip rates of the Sumatran Fault Zone in Southern Sumatra, Indonesia
}

\author{
Danny Hilman Natawidjaja ${ }^{*}$ (D), Kyle Bradley ${ }^{2}$, Mudrik R. Daryono ${ }^{1}$, Sonny Aribowo ${ }^{1}$ and Jason Herrin 2,3
}

\begin{abstract}
Over the last decade, studies of natural hazards in Sumatra have focused primarily on great earthquakes and associated tsunamis produced by rupture of the Sunda megathrust. However, the Sumatran Fault and the active volcanic arc present proximal hazards to populations on mainland Sumatra. At present, there is little reliable information on the maximum magnitudes and recurrence intervals of Sumatran Fault earthquakes, or the frequency of paroxysmal caldera-forming (VEI 7-8) eruptions. Here, we present new radiocarbon dates of paleosols buried under the voluminous Ranau Tuff that constrain the large caldera-forming eruption to around 33,830-33,450 calender year BP (95\% probability). We use the lateral displacement of river channels incised into the Ranau Tuff to constrain the long-term slip rate of two segments of the Sumatran Fault. South of Ranau Lake, the Kumering segment preserves isochronous right-lateral channel offsets of approximately $350 \pm 50 \mathrm{~m}$, yielding a minimum slip rate of $10.4 \pm 1.5 \mathrm{~mm} /$ year for the primary active fault trace. South of Suoh pull-apart depression, the West Semangko segment offsets the Semangko River by $230 \pm 60 \mathrm{~m}$, yielding an inferred slip rate of $6.8 \pm 1.8 \mathrm{~mm} /$ year. Compared with previous studies, these results indicate more recent high-volume volcanism in South Sumatra and increased seismic potency of the southernmost segments of the Sumatran Fault Zone.
\end{abstract}

Keywords: Ranau Tuff, Sumatran Fault, Neotectonics, Seismic hazard

\section{Background}

The $1650 \mathrm{~km}(\mathrm{~km})$ long Sumatran Fault Zone is a system of dominantly strike-slip fault segments that together accommodate much of the trench-parallel component of the oblique convergence between eastern Indian Ocean lithosphere and the overriding continental crust of the Sunda plate (Fig. 1). At its northern terminus, the Sumatran Fault Zone links with submarine strike-slip faults that transform into the active spreading centers of the Andaman Sea (Curray et al. 1979), and at its southern terminus, it ends within the large pull-apart basin of the Sunda Strait (Baroux et al. 1998; Bellier and Sebrier

\footnotetext{
*Correspondence: danny.hilman@gmail.com

${ }^{1}$ Research Center for Geotechnology, Indonesian Institute

of Geosciences, Bandung, Indonesia

Full list of author information is available at the end of the article
}

1995; McCaffrey 1991; McCarthy and Elders 1997; Sieh and Natawidjaja 2000). While the Sumatran Fault Zone has produced damaging moderate to large earthquakes during historical time, since 1950 A.D. (Anno Domini) large earthquakes have occurred significantly less frequently than expected. In the absence of a long historical earthquake record or detailed geophysical characterization of the active fault system, assessments of the hazard presented by the Sumatran Fault Zone must rely on detailed mapping of the fault segments and characterization of their rate of strain accumulation by measurement of Late Pleistocene to recent slip rates (Natawidjaja and Triyoso 2007). The most reliable geological slip rates of the Sumatran Fault are determined from lateral offsets of young, voluminous caldera tuffs and associated igneous units that were erupted onto the fault trace (Bradley et al. 2017; Sieh et al. 1991, 1994). Previous slip rate studies in 


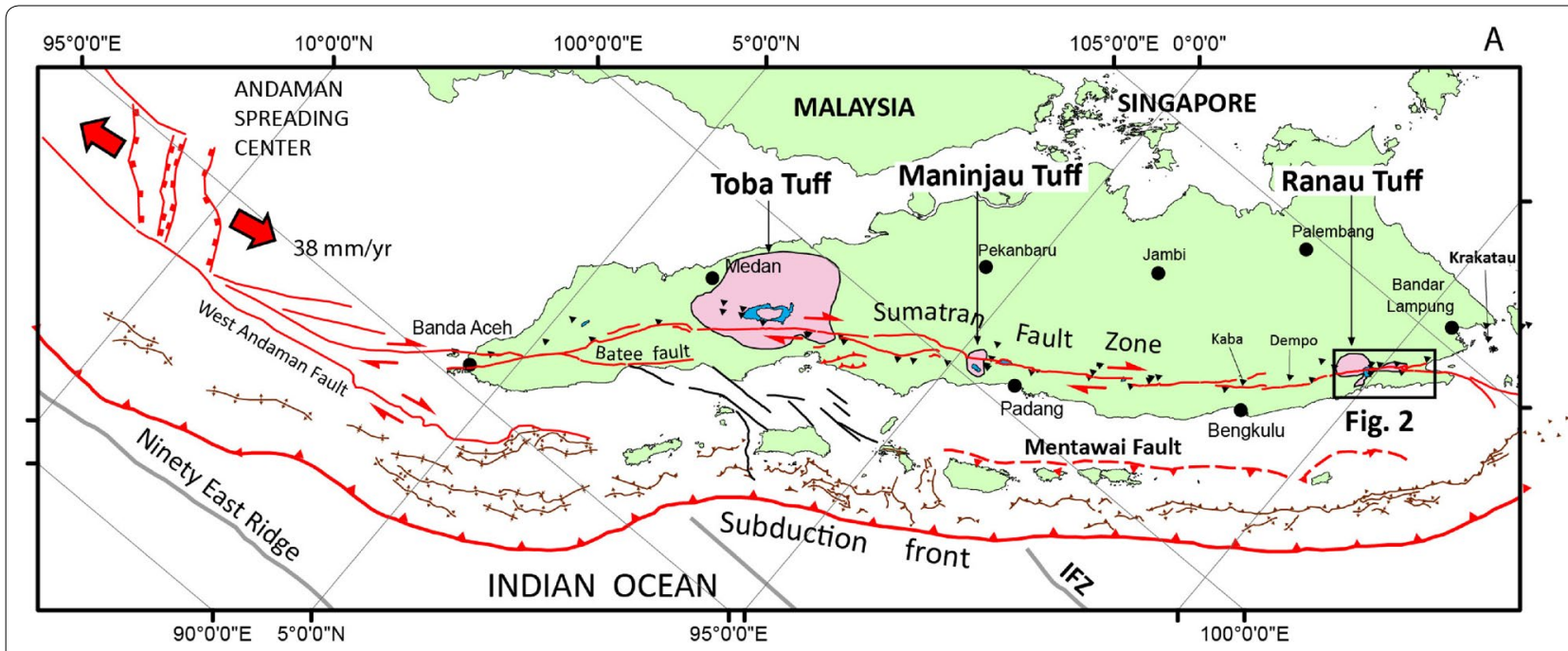

Fig. 1 Neotectonic setting of the Sumatran oblique convergent margin and locations of three large Quaternary rhyolitic tuffs along Sumatra Fault Zone. IFZ Investigator Fracture Zone

Southern Sumatra focused on lateral offsets of products of the Ranau Caldera (Bellier and Sebrier 1994), which has been proposed to be much older than other offset caldera complexes in Sumatra (Bellier et al. 1999). In this study, we show that the Ranau Caldera is the youngest such structure in Sumatra, and that the southernmost segments of Sumatran Fault have significantly faster rates than those inferred by previous studies.

\section{Active faulting in south sumatra}

The active faults of South Sumatra have previously been mapped using small-scale topographic maps and aerial photographs (Bellier et al. 1999; Bellier and Sebrier 1995; Sieh and Natawidjaja 2000). A recent evaluation of earlier studies shows that significant improvements can be made using more modern topographic and remote sensing data (Bradley et al. 2017). We remapped the southernmost 200 $\mathrm{km}$ of the Sumatran Fault Zone, consisting of the Kumering and Semangko fault segments and associated splay faults (Sieh and Natawidjaja 2000), using digital terrain data from Shuttle Radar Topographic Mission (SRTM) 1 Arc-Second (USGS 2015) and high-resolution satellite imagery from Google Earth.

The northern end of the Kumering segment is separated from Manna fault segment by a 7-km-wide contractional bend (Sieh and Natawidjaja 2000). Southward, along the Komering River longitudinal valley, the linear trace of the Kumering segment crosses the rhyolitic Ranau Tuff, other volcanic deposits, and alluvial sediments (Fig. 2). Several small river branches are dextrally offset along the fault trace, but due to the complexity of the drainage pattern it is difficult to measure total offsets. The fault crosses the Ranau Lake and develops a 3-km-wide extensional stepover on the east side of the Seminung volcanic edifice (Fig. 3a). Further south, the Kumering segment crosses the flat plain of the Liwa Basin that is underlain by thick Ranau Tuff deposits that are deeply incised by the Way Robok river. The Kumering segment in this location was previously called the Ranau-Suoh fault (Bellier and Sebrier 1994). A second fault trace can be observed running parallel to the Kumering segment within the high mountains west of the Liwa Basin. This fault, which we term the Ranau Fault (Fig. 3a), links the southwestern wall of the Ranau Caldera to the West Semangko segment further south. The trace of the Ranau fault is generally more geomorphically subdued than the Kumering fault, except in its central part that exhibits sharp lateral offsets of linear valleys and ridges.

The multiple strand geometry of the southern Sumatran Fault means that geological slip rates measured from single fault traces may only be minimum estimates of slip rates across the broader Sumatran Fault zone, and that slip rates estimated from GPS velocity profiles across the fault zone probably represent aggregate strain accumulation.

The Kumering segment branches southward into the West Semangko and East Semangko segments (Fig. 3b). The West Semangko segment was previously termed the Semangko Fault (Bellier and Sebrier 1994; Sieh and Natawidjaja 2000) and the East Semangko segment was previously called as the North Semangko fault (Bellier and Sebrier 1994). The Kumering segment is connected to the West Semangko segment by the 7-km-wide Suoh pull-apart (Fig. 3b). The normal faults that define the 


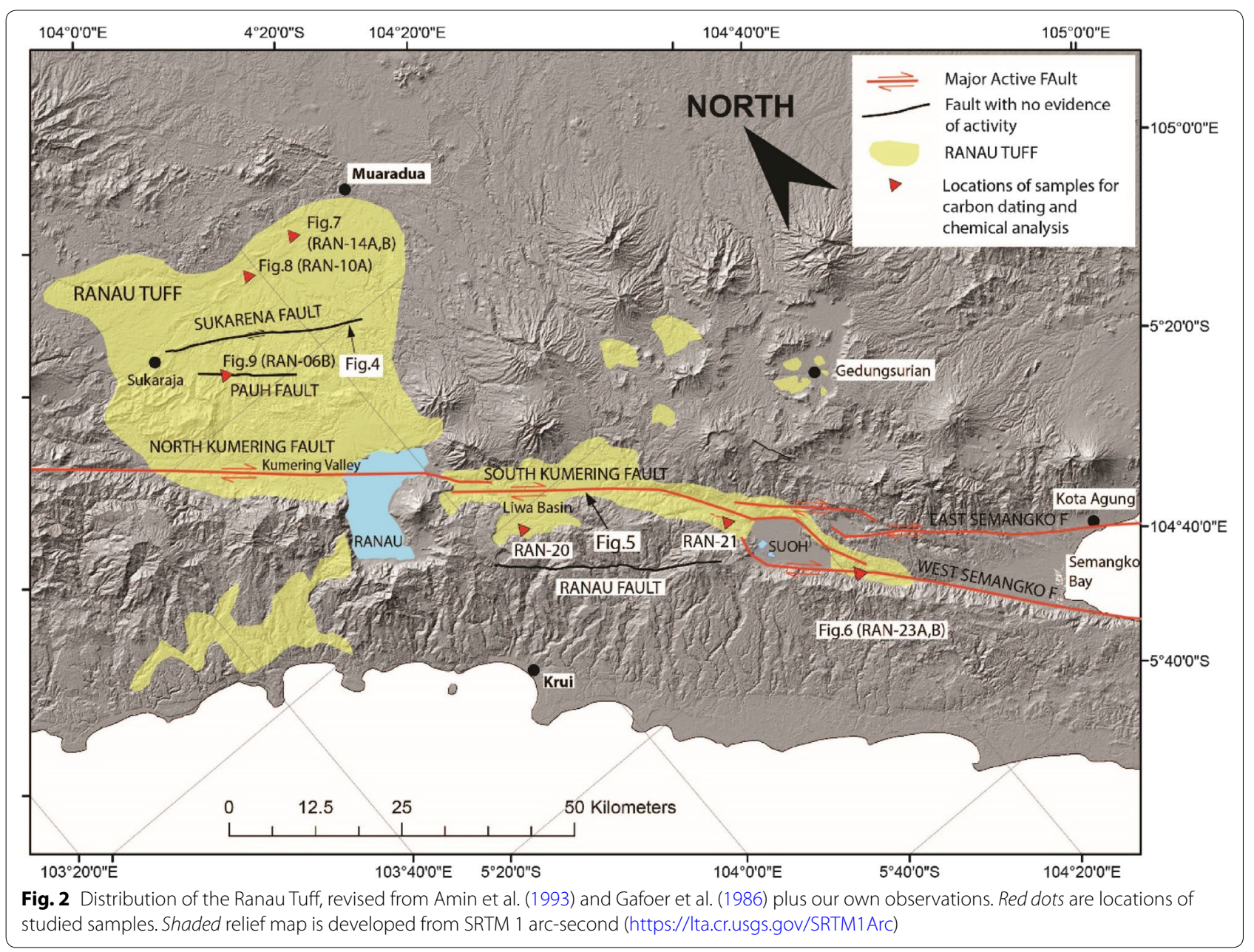

northwestern topographic margin of the Suoh valley are associated with an active geothermal field consisting of maar lakes, fumaroles, and hot springs, which has demonstrated enhanced activity immediately after historical earthquakes. Two weeks after the 1933 Liwa earthquake, a phreatic eruption from Suoh covered the nearby valley floor with ejecta and killed numerous inhabitants (Stehn 1934). Following the 1994 Liwa earthquake, which appears to have been limited in rupture extent by the Suoh stepover, there was sudden increase in geothermal activity as well as several phreatic eruptions (Natawidjaja 1994; Widiwijayanti et al. 1996).

The Kumering segment is connected to the East Semangko segment by the 3-km-wide Natarang pullapart, on the east side of Suoh (Fig. 3b). The southern part of the East Semangko fault gradually loses its topographic expression within alluvial deposits, and appears to radiate into several branches that disappear before reaching the Semangko Bay. This structural radiation pattern, seen along strike-slip faults elsewhere, has been called a horsetail structure and commonly marks the termination of a strike-slip fault zone. However, bathymetric data from Semangko Bay suggest that a strike-slip fault continues southeastward and forms the northern boundary of the Sunda Strait pull-apart. The West Semangko segment defines the eastern edge of the Barisan Range, and continues beneath the sea along the west side of the Semangko Bay where it forms the southern edge of the Sunda Strait pull-apart basin (Susilohadi et al. 2009).

Far northeast of Ranau lake, we observe two secondary fault lines that run parallel to the Kumering segment, which we term the Sukarena and Pauh Faults (Fig. 2). Field observations indicate that while these faults do exist in outcrop, there are few geomorphic indications of recent fault motion. A fresh road cut exposes the southern end of Sukarena Fault outcrop on the main road between Ranau Lake and Muaradua town (Fig. 4). There, the fault cuts tilted Tertiary sedimentary rocks but is sealed by the Ranau Tuff, indicating inactivity since the last eruption. 


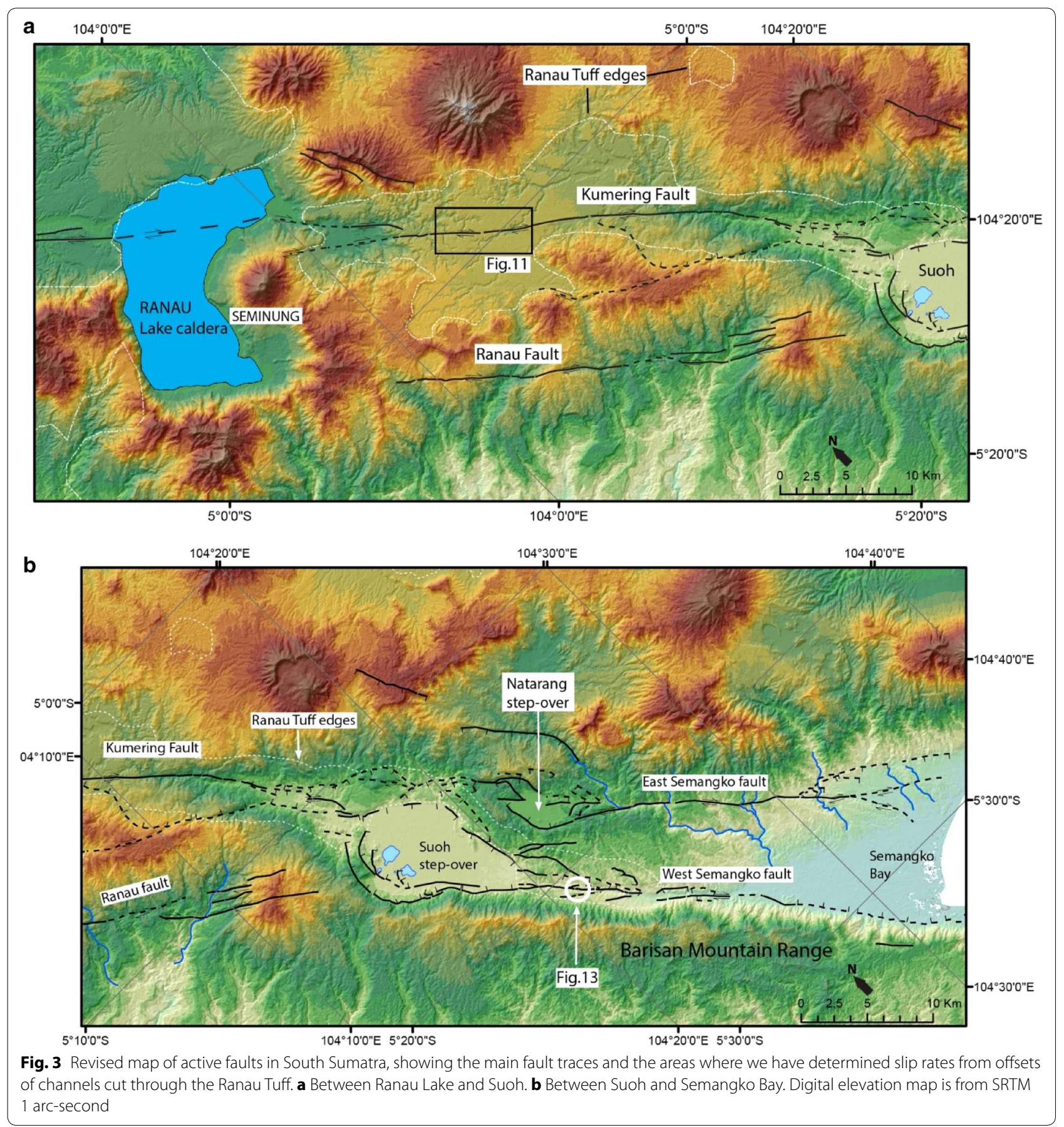

\section{Age of Ranau Tuff}

The remnant of the center of the paroxysmal eruptions of Ranau Tuff is a $14-\mathrm{km}$-long and 8-km-wide rectangular caldera that is filled by Ranau lake (Fig. 2). The southeastern edge of this lake is defined by the apron of the conical Seminung Volcano, which exhibits fresh flow and crater morphology indicating Holocene activity. The rectangular shape of the caldera lake may reflect structural control by strands of the Sumatran Fault (Bellier and Sebrier 1994). The Ranau Tuff blanketed a wide area within a $\sim 70 \mathrm{~km}$ radius of Ranau Lake (Amin et al. 1993; Gafoer et al. 1993). In the proximal area, southeast of the lake, thick tuffs with large pumices and lithic fragments filled the Liwa Basin (Fig. 5). In more distal areas, the Ranau Tuff bed is finer and thinner (Figs. 6, $7,8,9)$. 


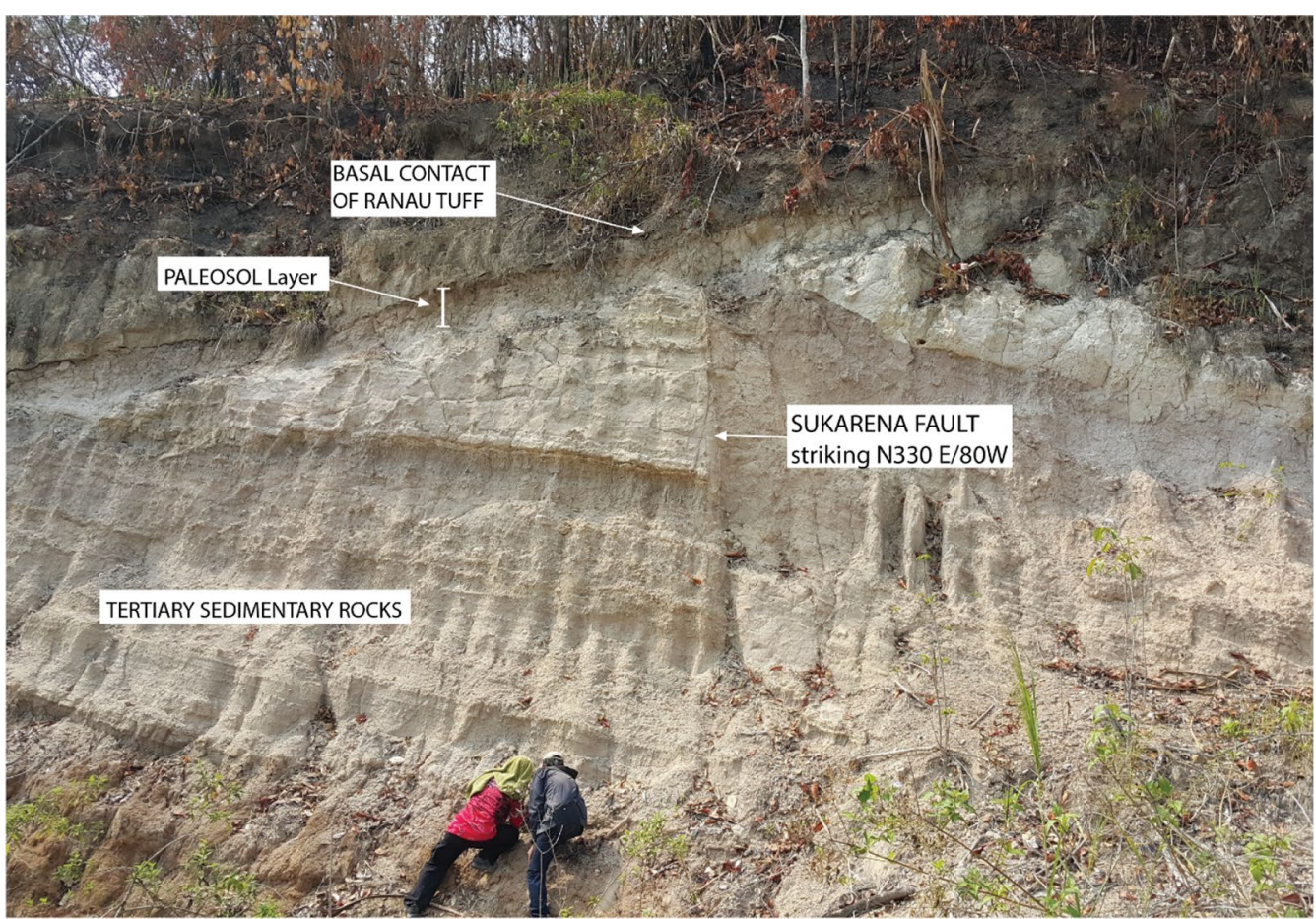

Fig. 4 Road cut exposure (Lat, Lon: -4.669773, 104.050126) between Muaradua and Ranau Lake of the inactive Sukarena Fault, which is overlain by the undeformed Ranau Tuff. Location of this outcrop is marked in Fig. 2
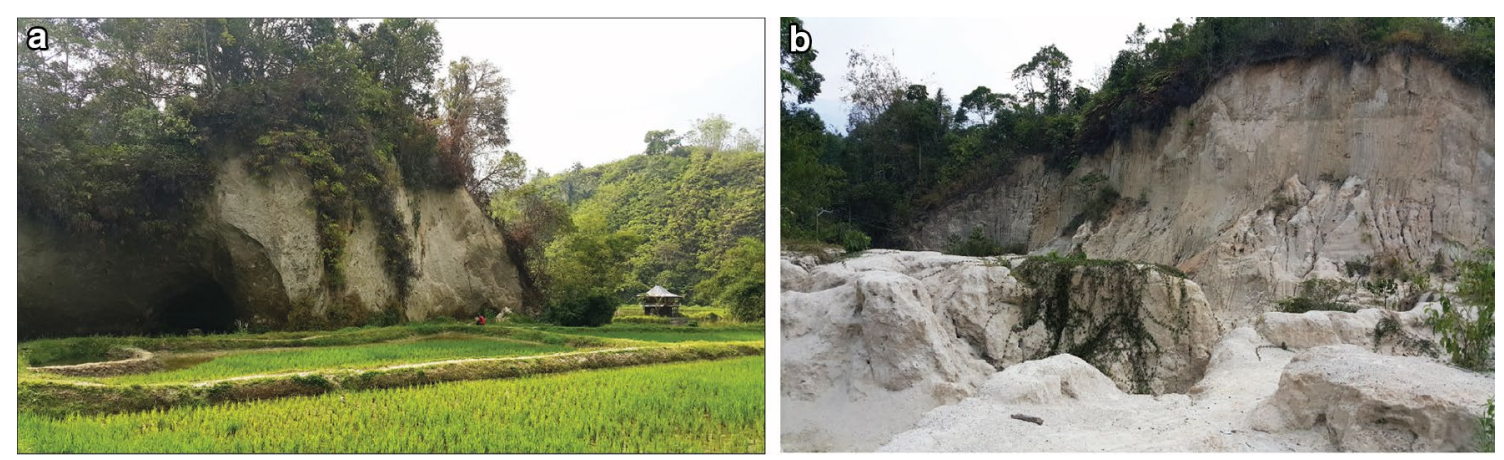

Fig. 5 Examples of exposures of the proximal Ranau Tuff within $10 \mathrm{~km}$ of the eruptive center. a South of Ranau Lake within the Liwa Valley, b North of Ranau Lake within the Kumering River Valley

Sumatra is well known for its unusually high number of large caldera systems. Paroxysmal eruptions from these systems have produced enormous rhyolitic tephra deposits that blanket large portions of the Sumatran Fault. These outflow sheets include the Young Toba Tuff in north Sumatra (Chesner et al. 1991), the Maninjau Tuff in central Sumatra (Alloway 2004) and the Ranau Tuff in south Sumatra (Hochstein and Sudarman 1993; Westerveld 1952). Rapid emplacement of huge volumes of tephra causes immediate obfuscation of pre-emplacement landscapes. The new river drainages rapidly evolve from early disconnected streams into dendritic networks via deep incision of the thick, non-welded tuffs. These networks of rivers, in several locations, cross the active trace of the Sumatran Fault Zone, producing systematic right-lateral offsets of nearly isochronous river canyons. The average fault slip rate since eruption is simply determined by dividing the average offset by the eruption age (Bradley et al. 2017; Sieh and Natawidjaja 2000).

The eruption age of the Ranau Tuff corresponds with the regional resetting of the geomorphic landscape, and has previously been estimated from ${ }^{40} \mathrm{~K}-{ }^{40} \mathrm{Ar}$ 

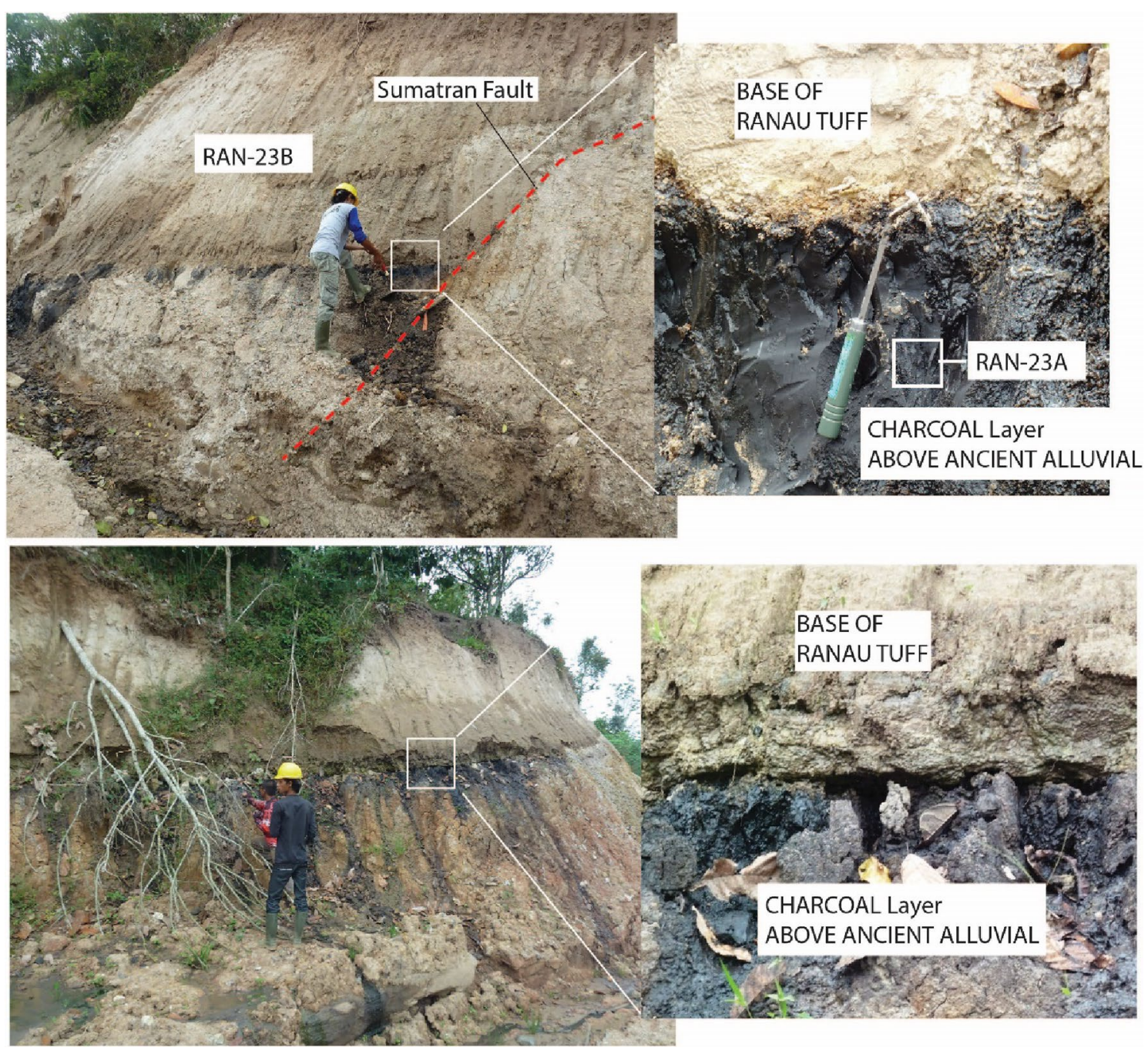

Fig. 6 Two outcrops of the distal Ranau Tuff in the Semangko Valley $50 \mathrm{~km}$ from the eruptive center, showing several meters of fine-grained tuff overlying a layer of charcoal on top of alluvial sediments. a At site 1 (Lat,lon: -5.34028, 104.34593). b At site 2 (lat,lon: -5.34319, 104.34687) about 350 m from site 1

(Kalium-Argon) dating of glass and phenocrysts separated from pumice (Bellier et al. 1999). Bellier et al. (1999) reported ${ }^{40} \mathrm{~K}-{ }^{40} \mathrm{Ar}$ ages of $1 \mathrm{~g}$ whole rock separates $(0.73 \pm 0.13 \mathrm{Ma}), 0.7-0.8 \mathrm{~g}$ groundmass separates $(0.66 \pm 0.18 \mathrm{Ma})$, and $0.6-0.8 \mathrm{~g}$ feldspar separates $(0.55 \pm 0.15 \mathrm{Ma})$. These authors interpreted the feldspar age as best reflecting the eruption age, although they noted that the significantly older whole rock and groundmass ages probably reflect contamination by excess (nonradiogenic) ${ }^{40} \mathrm{Ar}$ from an unidentified source. This age appears to be too old to reflect the eruptive age of the geomorphically fresh Ranau Tuff, which is the youngest eruptive unit in a volcanically active region. Given the bulk separate preparation methods, it is likely that this age is affected by excess argon contained in abundant melt inclusions within phenocrysts and along grain boundaries (Owens et al. 1999). Due to the low proportion of radiogenic versus atmospheric argon within the Ranau Tuff ( $\sim 10 \%$ for plagioclase feldspar, $<5 \%$ for whole rock and groundmass), even small amounts of excess argon would result in a significant overestimation of the true eruption age.

We surveyed distal areas $(>20 \mathrm{~km}$ from the caldera rim) where the basal contact of the Ranau Tuff was more likely to be exposed in road cuts and quarries (Figs. 6, 7, 8 , 9). Radiocarbon dates of charcoals and organic-rich soils that are preserved along the basal contact of the tuff provide a maximum age of the emplacement, if the possibility of contamination by younger carbon can be sufficiently ruled out. AMS (Accelerator Mass Spectrometry) radiocarbon ages were determined by the BETA Analytic Laboratory and are corrected for variations in 


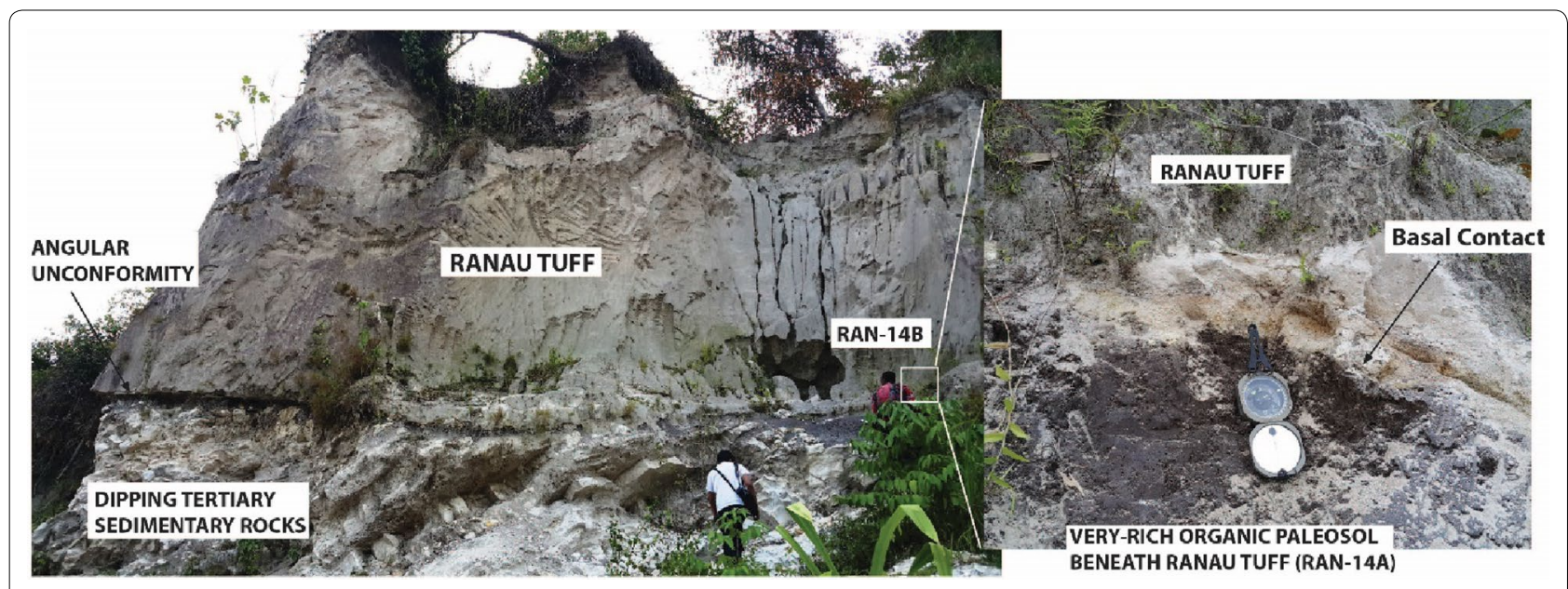

Fig. 7 Exposures of the distal Ranau Tuff near Muaradua (Lat,Lon: $-4.53182,104.06358), 40 \mathrm{~km}$ from the eruptive center, where samples RAN-14A,B were collected. The tuff is separated from tilted sedimentary rocks by a thick, organic-rich paleosol

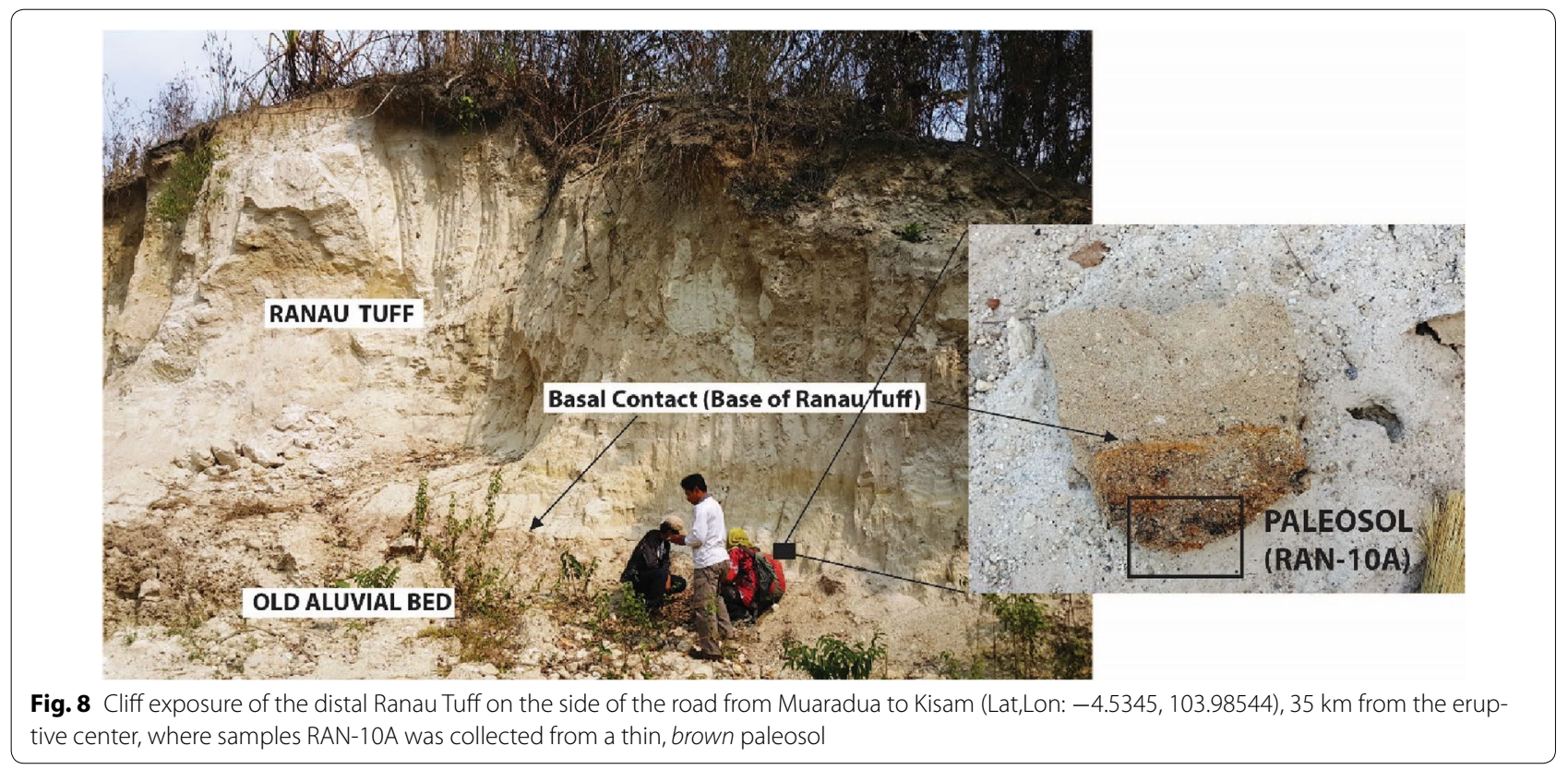

atmospheric $\mathrm{CO}_{2}$ reservoirs over time using the SHCal13 calibration (Hogg et al. 2013). We examined five exposures where the basal contact of the distal Ranau Tuff overlies buried paleosols.

In the Semangko River valley, just south of Suoh pullapart and $70 \mathrm{~km}$ from Ranau Lake, the Ranau Tuff bed is several meters thick and mantles the surface of the present landscape (Fig. 6). Along a fresh road cut in an ongoing construction of a new hydroelectric power plan, there are two exposures exhibiting thick layers of charcoal, located on top of paleosols and immediately beneath the ash flow deposit (Fig. 6). We sampled RAN23A from a half-meter thick layer of charcoal that was cut by an active fault strand (Fig. 6a). The result yields a conventional carbon age of 29,440 \pm 140 radiocarbon years $\mathrm{BP}$, corresponding with a corrected calendar-year age of $33,830-33,450$ cal year BP (95\% probability) (Table 1 ).

On the cliff exposures at the quarry along the main road near Muaradua town, $40 \mathrm{~km}$ northeast of Ranau Lake, a 4-5-m-thick Ranau Tuff bed overlies moderately tilted Tertiary sedimentary rocks (Fig. 7). Between the tilted sediments and the tephra is a few tens of $\mathrm{cm}$ thick of organic-rich paleosol. This dark-gray soil, however, is not as black, rich, and pure in organics as that of RAN-23A charcoal sample. We carefully avoided carbon contamination from modern plants and roots during collection of 

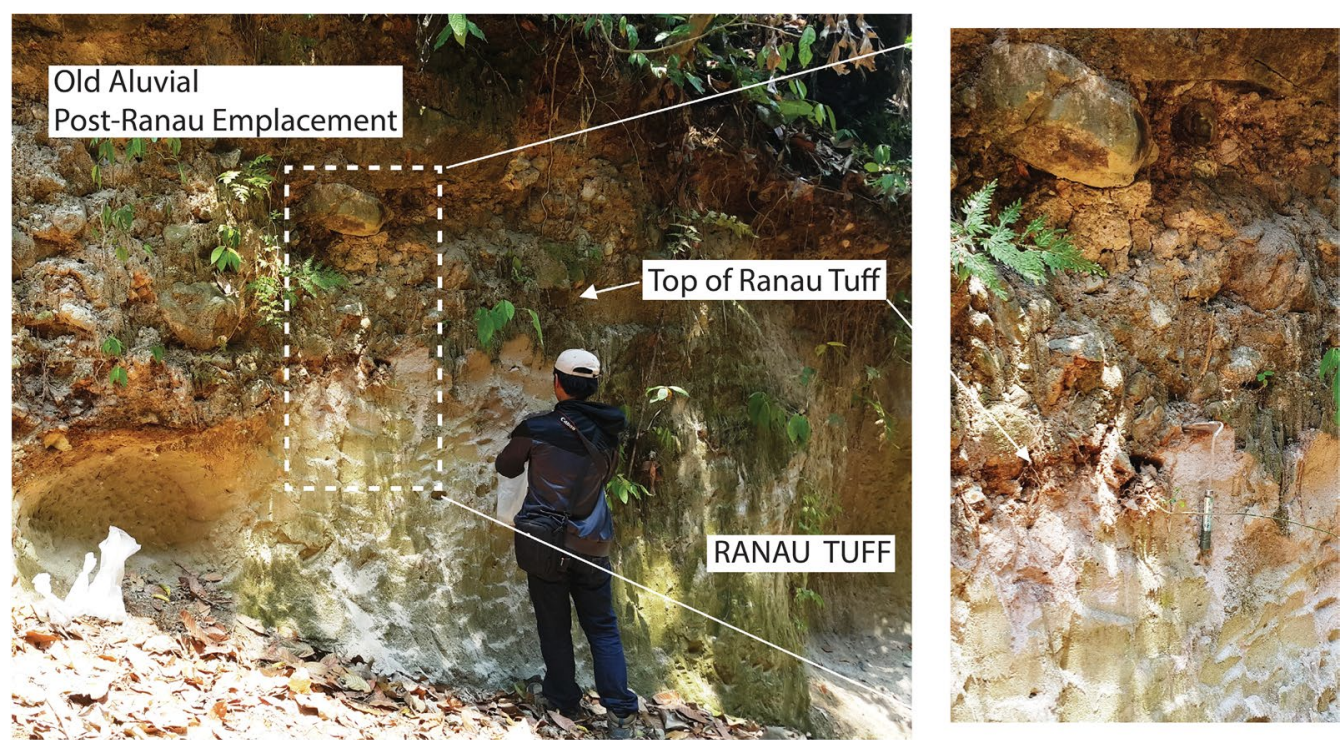

a

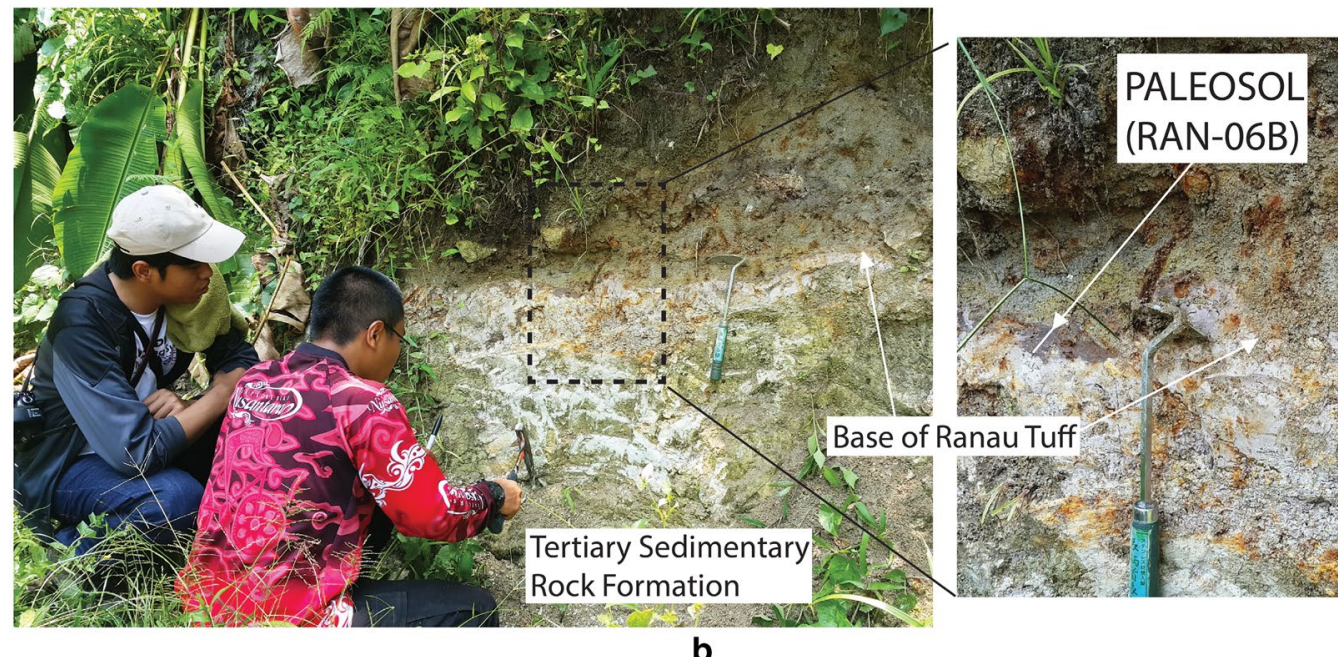

Fig. 9 Exposure of the distal Ranau Tuff along the trace of the Pauh Fault, $20 \mathrm{~km}$ from the eruptive center near Sukabumi village (Lat,Lon: -4.61433, 103.88004). a Top of Ranau Tuff overlain by old alluvial deposit. b Base of Ranau Tuff overlying the Tertiary sandstone. RAN-06B sample is collected from a thin, light gray paleosol

this sample. The AMS analysis of this sample (RAN-14A) yields a conventional carbon age of $26,830 \pm 140$ year $\mathrm{BP}$, corresponding with a corrected calendar-year age of $31,085-30,805$ cal year BP (95\% probability) (Table 1), slightly younger then the RAN-23A date.

Two other basal outcrops of the distal Ranau Tuff exposed only lower quality carbon materials. A cliff at a quarry, located $10 \mathrm{~km}$ west from RAN-14 site, exposes Ranau Tuff overlying gravels and sands in a weathered outcrop, covered and infiltrated by some modern vegetation and roots (Fig. 8). Organic material carefully separated from brown paleosol (RAN-10A) yielded a conventional carbon age of $18,160 \pm 70$ year BP or $22,145-21,810$ cal year BP, significantly younger than that of RAN-14A and RAN-23A, clearly because of contaminations by modern carbon. Another site at an old road cut heading to a proposed water dam, located $20 \mathrm{~km}$ to the southwest of RAN-10, exposes the Ranau Tuff overlying a thin gray paleosol layer developed on top of Tertiary sandstone (Fig. 9). Organic material separated from this paleosol (RAN-06B) yielded a conventional carbon age of $11,750 \pm 50$ year BP, much younger than others as expected because of appearance contaminations of modern carbon. 
Table 1 Results of the AMS radiocarbon age analysis, on paleosols underlain Ranau tuffs, conducted at BETA Analytic (http://www.radiocarbon.com/)

\begin{tabular}{|c|c|c|c|c|c|c|c|c|}
\hline \multicolumn{2}{|c|}{ Sample code } & \multirow{2}{*}{$\begin{array}{l}\text { Field } \\
\text { descriptions }\end{array}$} & \multirow{2}{*}{$\begin{array}{l}\text { Measured } \\
\text { radiocarbon } \\
\text { age }\end{array}$} & \multirow[t]{2}{*}{$\delta^{13} \mathrm{C}(\% \circ)$} & \multirow{2}{*}{$\begin{array}{l}\text { Conventional } \\
\text { radiocarbon age } \\
\text { (rcy BP) }\end{array}$} & \multicolumn{3}{|c|}{ Calendar age calibration (cal year BP) } \\
\hline Field & BETA & & & & & $\begin{array}{l}\text { Median } \\
\text { modeled age }\end{array}$ & $2 \sigma-95 \%$ Prob. & $1 \sigma-65 \%$ Prob. \\
\hline RAN-23A & Beta-396325 & $\begin{array}{l}\text { Charcoal, black, } \\
\text { no sign of con- } \\
\text { tamination }\end{array}$ & $29,230 \pm 140 \mathrm{BP}$ & -11.9 & $29,440 \pm 140$ & 33,650 & $33,830-33,415$ & $33,740-33,545$ \\
\hline RAN-14A & Beta-423698 & $\begin{array}{l}\text { Dark-gray, very- } \\
\text { rich organic soil, } \\
\text { possibly some } \\
\text { contamination }\end{array}$ & $26,630 \pm 140 \mathrm{BP}$ & -12.9 & $26,830 \pm 140$ & 30,960 & $31,085-30,805$ & $31,025-30,885$ \\
\hline RAN-10A & $\begin{array}{l}\text { Beta- } \\
\quad 423,697\end{array}$ & $\begin{array}{l}\text { Gray, organic soil, } \\
\text { evidence of } \\
\text { more contami- } \\
\text { nation }\end{array}$ & $17,990 \pm 70 \mathrm{BP}$ & -14.9 & $18,160 \pm 70$ & 21,915 & $22,145-21,810$ & $21,990-21,860$ \\
\hline RAN-06B & $\begin{array}{l}\text { Beta- } \\
\quad 423,699\end{array}$ & $\begin{array}{l}\text { Lighter gray, less } \\
\text { organic soil, evi- } \\
\text { dence of much } \\
\text { contamination }\end{array}$ & $11,650 \pm 50 \mathrm{BP}$ & -18.6 & $11,750 \pm 50$ & $\begin{array}{l}13,545 \\
13,510 \\
13,495\end{array}$ & $13,585-13,445$ & $13,565-13,470$ \\
\hline
\end{tabular}

The calibration used mathematical approach developed by Talma and Vogel (1993) with reference to SHCAL 13 database (Hogg et al. 2013)

Based on our assessment of the quality of preservation and degree of modern contamination of the carbon-rich sediments underlying the Ranau Tuff in four locations, we interpret that the best estimate of the Ranau Tuff emplacement is the resulting age of RAN-23A sample, because it was collected from a thick layer of charcoal with no outward signs of contamination. The samples of the other three locations indicate that the ash flow deposit at RAN-23B is the same Ranau Tuff layer as observed in the northern part. This is best demonstrated by RAN-14A that yields the most similar age to RAN23A. Another purpose of this exercise is also to show that the appearance contaminations of modern vegetation significantly affect the results.

While the dated tephra appear to correspond with a single eruptive unit based on field comparisons, the large distance between exposures means that it is possible that we have sampled separate eruptive units of different age. To test this, we measured major and minor element compositions of phenocryst phases and glass for four samples collected from three distal outcrops of tephra believed to be the Ranau Tuff (RAN-23B, RAN-14B, RAN-21 at Fig. 2), and one outcrop near Liwa (RAN-20 at Fig. 2).

Compositions of individual phases were determined using a JEOL JXA-8530F Field Emission Electron Probe Microanalyzer (EPMA) at the Earth Observatory of Singapore employing a $10 \mathrm{nA}$ beam current, $15 \mathrm{kV}$ accelerating voltage, and $10 \hat{\mathrm{A}} \mu \mathrm{m}$ beam diameter for counting times of 10-40 s. Results were quantified using wellcharacterized natural and synthetic calibration standards. Background intensities were empirically calibrated to an absorption-corrected continuum based on mean atomic number (Donovan and Tingle 1996). Oxygen was calculated by cation stoichiometry and included in the matrix correction. An interference correction was applied to Fe for interference by Mn. Analytical uncertainty at the $99 \%$ confidence level was less than $1 \%$ of all reported values.

The mineralogy of pumices separated from these samples is consistent with the previous descriptions of the Ranau Tuff (Bellier et al. 1999). Glass shard $\mathrm{SiO}_{2}$ ranges from 75 to 79 wt \% (recast to a volatile-free basis). All plagioclase feldspars are andesine $\left(\mathrm{An}_{27}-\mathrm{An}_{40}\right)$. Glass, biotite, titanomagnetite, and ilmenite from all samples have comparable major element compositions (Fig. 10). Sample RAN-23B yielded additional phases with distinct major element compositions compared with other Ranau Tuff samples (Fig. 10e), which may represent contamination of the very distal tephra during emplacement or reworking. Of the large Late Pleistocene rhyolitic tephras of Sumatra, the Ranau Tuff is most similar in composition to the V-6 tephra (Fig. 10) sampled via drill core within trench slope sediments north of Enggano (Salisbury et al. 2012). The age of this tephra is not directly constrained from the drill core, but is estimated at $27.53 \pm 0.48 \mathrm{ka}$ based on extrapolation of slope sedimentation rates calculated from ${ }^{14} \mathrm{C}$ ages of planktic foraminifera from other drill cores located far from the V-6 sampling site. The compositional and age similarity of the Ranau Tuff and the V-6 tephra suggest that they are likely correlative.

\section{Fault slip rates}

Slip rate of the Kumering segment

Bellier et al. (1999) proposed a collection of geomorphic features that are right-laterally offset about $2.5 \mathrm{~km}$ along 


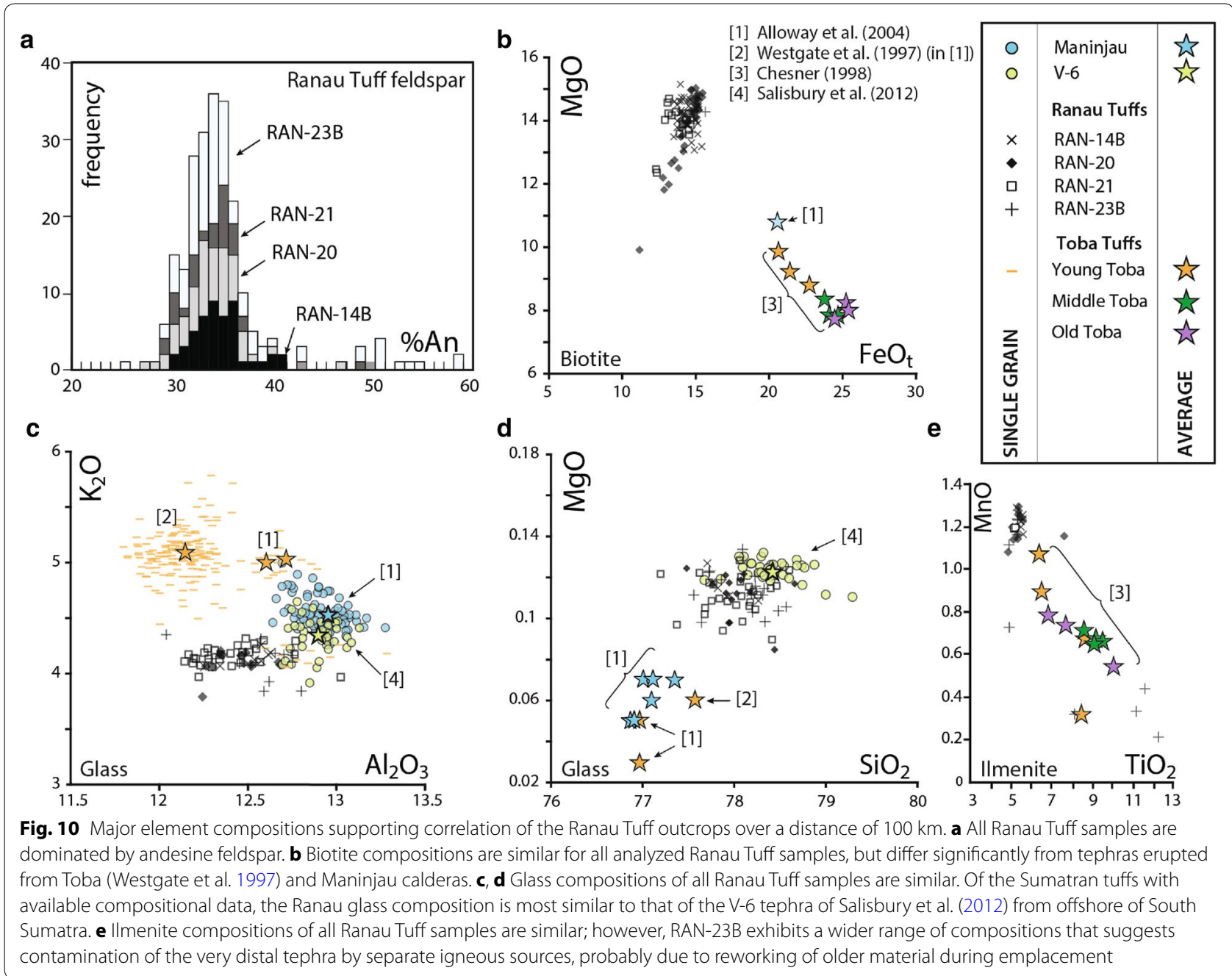

the Sumatran Fault on the south side of the Ranau Lake. The features include a tectonic lineament, the southeastern rim of the Ranau caldera, the Robok River channel, and several tributaries of a dendritic river system that flows northward into the lake. Hence, based on their KAr dating of plagioclase of the Ranau Tuff that yielded an average age of $0.55 \pm 0.15 \mathrm{Ma}$ (Million years ago), and assuming those geomorphic features were formed right after the paroxysmal eruption of Ranau Tuff blanketed the old topography, they estimated a slip rate of $5.5 \pm 1.9 \mathrm{~mm} /$ year (millimeter/year) for the Kumering Fault (or they called it as the Ranau-Suoh fault). We disagree with the K-Ar dates as discussed above, and we also dispute the offset by the following arguments. First, the eastern edge of the caldera is not offset by $2.5 \mathrm{~km}$ east of Gunung Seminung, but is identifiable as a topographic escarpment that continues across the Sumatran Fault and is buried by the active caldera rim volcano. Second, the Way Robok River is not offset by $\sim 2.5 \mathrm{~km}$ (kilometer), as there is no remnant of a fault-crossing channel near its proposed northern truncation. Instead, several river channels south of the Lake i.e., Way Rekuk, Way Menjadi, and Way Heni do have a right-lateral offset where it crosses the fault but with a much smaller amount of offset as described in the following paragraph.

Southeast of Ranau lake, the straight Kumering segment runs through the thick, flat-topped Ranau Tuff that fills the Liwa basin. The fault trace coincides with a sequence of five right-lateral deflections of deeply incised river canyons of Way Rekuk, Way Menjadi, Way Heni, and Way Robok (Fig. 11). The similar amounts of deflection indicate that the canyons developed isochronously. Three of the displaced canyons cross the fault at a nearly orthogonal angle, and together yield an estimated total fault offset of 320-380 m, where the offset uncertainty is equivalent to the width of the displaced canyons. Two offset channels cross the fault trace at a lower angle and therefore yield less accurate estimates 


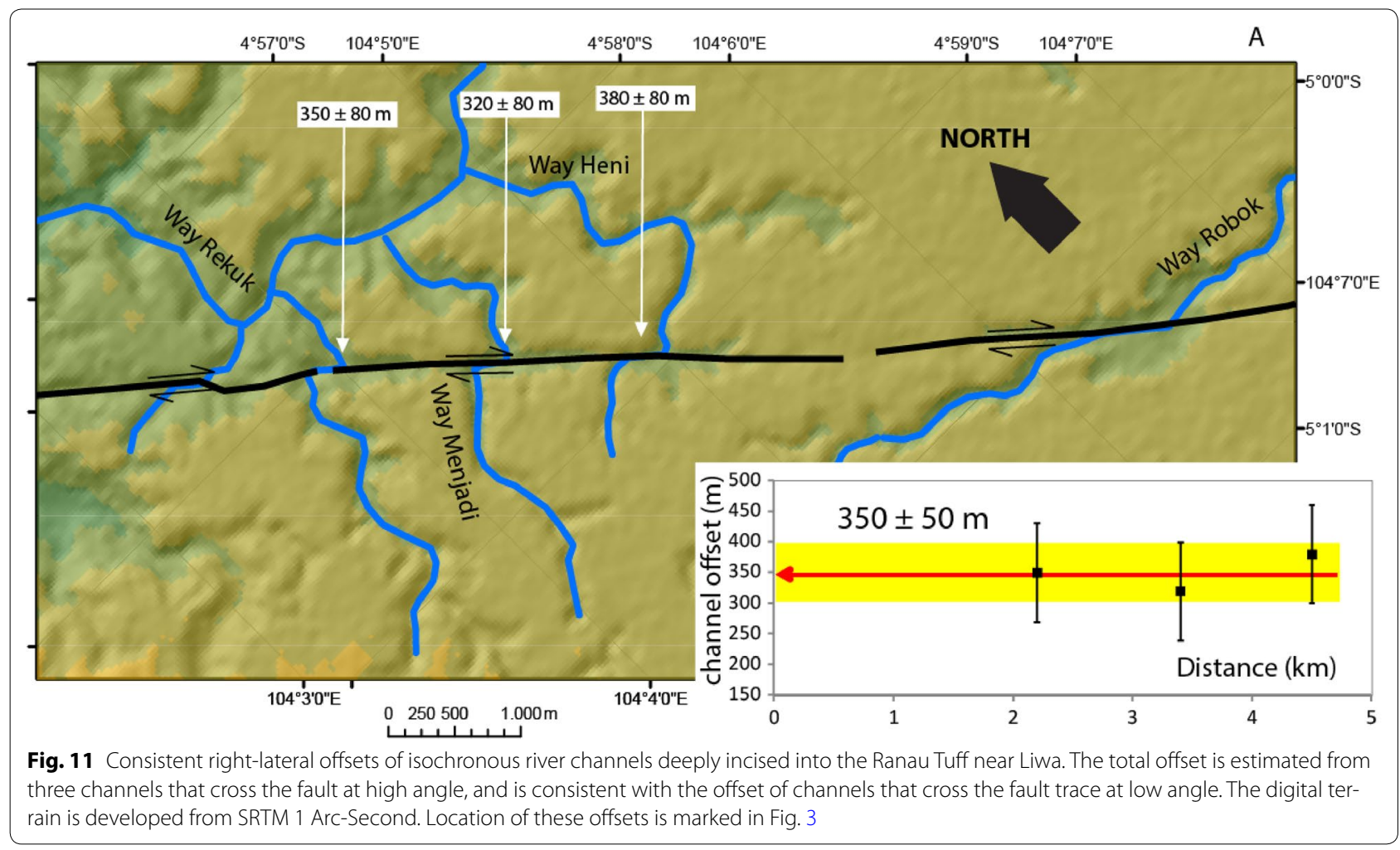

of total offset; however, the magnitude of the offset is consistent with the three orthogonal channels. The average of the three best offsets is $350 \pm 50 \mathrm{~m}$ (meter) (Fig. 11). The estimated eruption age of the Ranau Tuff, $33,830-33,450 \mathrm{cal}$ year BP (or 33,640 $\pm 190 \mathrm{cal}$ year BP), is considered as the approximated time of the initial incision of the valley since after the eruption and deposition of Ranau Tuff. Taking into account error propagation due to uncorrelated and random uncertainties of the offset measurement $(\delta \mathrm{d})$ and time of initial incision $(\delta t)$, the slip rate, $v$, can be calculated as follows:

$$
\begin{aligned}
v & =d / t, \text { and uncertainty in slip rate, } \\
\delta v & =v \times\left[(\delta d / d)^{2}+(\delta t / t)^{2}\right]^{0.5}
\end{aligned}
$$

Hence, slip rate on the Kumering segment is $10.4 \pm 1.5 \mathrm{~mm} /$ year.

\section{Slip rate of the Semangko segment}

South of the Suoh pull-apart basin, the west Semangko fault runs parallel to the Semangko River. At one locality, the river course turns and crosses the fault trace at a right angle. Taking advantage of fresh road cuts built to support a hydroelectric power plant, we conducted a Ground Penetrating Radar (GPR) survey together with geological-outcrop observations aimed at locating the principal active strands of the Semangko segment (Fig. 12).

In outcrop, we observed the fault zone as several widely spaced $(50-100 \mathrm{~m})$ vertical zones of sheared and striated clay stones juxtaposing different stratigraphic units. The principal fault strand is located on the western edge of the broader fault zone and is associated with a narrow valley. The GPR radargram (Fig. 12) clearly shows these three fault strands. The major fault strand is associated with right-lateral offset of the Semangko River where it flows at almost right angle across the fault (Fig. 13a). Elsewhere the major river runs parallel or cut the fault strand at low angle (Fig. 13b). The estimated total right-lateral offset of the Semangko River at this site is $230 \pm 60 \mathrm{~m}$, taken the width of the river valley as the uncertainty of the offset measurement. Restoration of this lateral offset yields reasonable matches for surrounding geomorphic features (Fig. 13c). Using the similar approach, the longterm slip rate estimated from this single river offset is therefore $6.8 \pm 1.8 \mathrm{~mm} /$ year.

The $M_{\mathrm{S}} 7.5$ June 25, 1933 Liwa-Kota Agung earthquake was one of the largest historical events produced by rupture of the Sumatran Fault, and caused significant damage over a region stretching from north of Ranau Lake to Kota Agung in the Sunda Strait (Berlage 1934). The great extent of reported damage indicates that fault rupture 

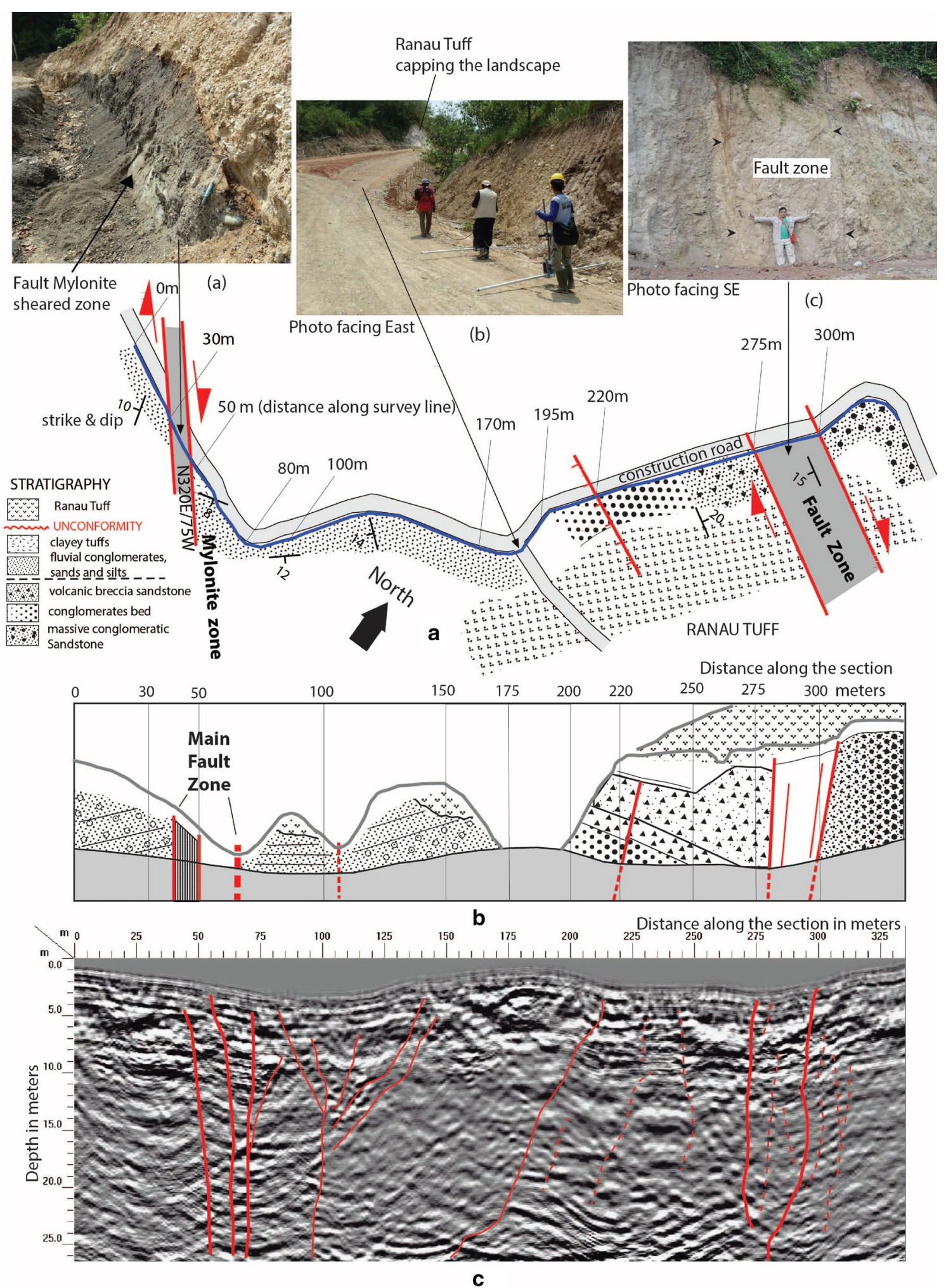

Fig. 12 Geological sections and radargram GPR along Survey Line 3 (location marked in Fig. 13) crossing west Semangko segment. a Geological map and stratigraphy along the survey line; $a, b, c$ are photographs of the outcrops on cliff along the line. $\mathbf{b}$ Schematic geological cross section facing the cliff along the survey line. c Ground Penetration Radar profile (radargram) along the survey line correlated to $\mathbf{b}$ 

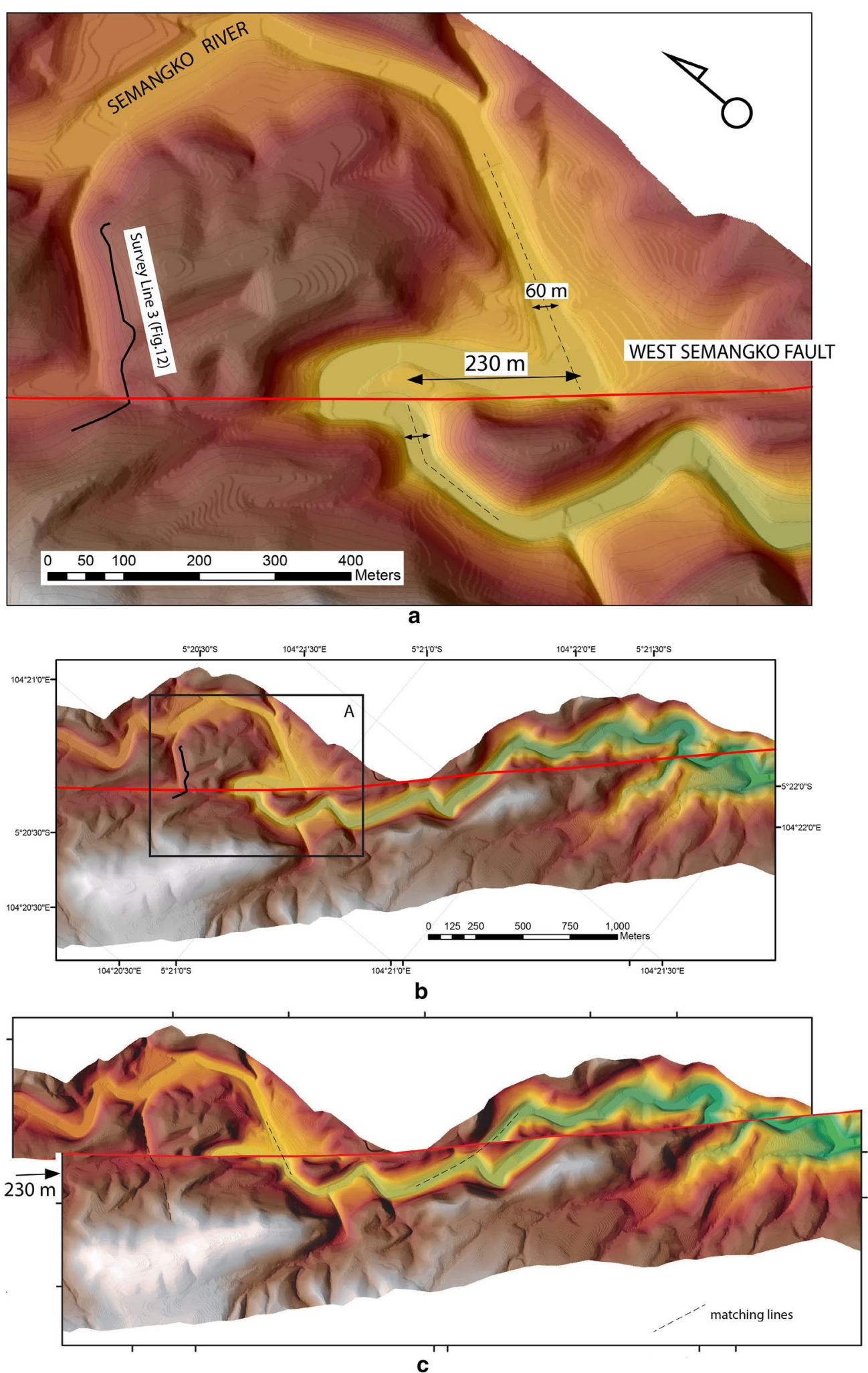

Fig. 13 a, b Single right-lateral offset of the Semangko River where it crosses the main active trace of the West Semangko Fault, south of Suoh (location is marked at Fig. 3). Channel incision at this site postdates eruption of the Ranau Tuff. The high-resolution digital terrain is developed from local topographic contour map for the Hydroelectric plan constructions. c Restoration of old topography before $230 \mathrm{~m}$ right-lateral movement. Slip rate is $6.8 \pm 1.8 \mathrm{~mm} /$ year taking into account the width of the river valley $(\sim 60 \mathrm{~m})$ as the uncertainty of measurement 
extended both north and south of the Suoh pull-apart basin, which occupies a $\sim 7 \mathrm{~km}$ right stepover between the Kumering and West Semangko segments that should present a significant barrier to rupture propagation. If the West Semangko segment did rupture during the 1933 earthquake, then we must conclude that the rupture propagated across the Suoh segment boundary, implying that multiple segment ruptures of the Sumatran Fault are possible and should be included in hazard assessments. However, if instead the East Semangko segment ruptured, then there would have been no significant barrier to the propagation of the rupture from the Sunda Strait to Ranau Lake. Further paleoseismic investigation of the 1933 rupture will therefore be important for understanding the rupture mechanics of the segmented Sumatran Fault Zone.

\section{Conclusions}

The new ${ }^{14} \mathrm{C}$ age for the Ranau Tuff indicates that it was emplaced during the youngest known large rhyolitic eruption in Sumatra. This increases the number of known Volcanic Explosivity Index (VEI)7 + events in Sumatra over the last $100 \mathrm{k}$ year (kilo year) from two to three. At present, there is little information about earlier possible eruptions from the caldera (as at Toba), or whether a stratovolcano existed at the location of the caldera prior to its collapse (as at Maninjau). While the main strand of the Sumatran Fault currently cuts straight across the caldera edifice, the position of the caldera between two active fault strands suggests a strong structural control on its formation (Bellier et al. 1999). Further studies of the relationship between active faulting and volcanism in this area are critical for understanding regional geohazards.

The Kumering segment has slipped at an average rate of $10.4 \pm 1.5 \mathrm{~mm} /$ year over the last $\sim 33 \mathrm{k}$ year. South of the Suoh pull-apart depression, the Sumatran Fault Zone branches into the West and East Semangko faults. The West Semangko Fault has a measured slip rate of $6.8 \pm 1.8 \mathrm{~mm}$, then we can infer that the East Semangko Fault slip rate is about $3.6 \mathrm{~mm} /$ year. These slip rate values, however, can be viewed as a minimum estimate due to the uncertain period of time between eruption and initial incision of the offset channels.

The slip rate of the Sumatran Fault Zone has been postulated to increase significantly from south to north (Baroux et al. 1998; McCaffrey, 1991; Sieh and Natawidjaja 2000). However, the slip rate data that support this model are highly unreliable (Bradley et al. 2017). Our revised slip rates for the Kumering and West Semangko segments are significantly faster than previous estimates (Bellier et al. 1999). GPS velocities from the SuGAr network (Bradley et al. 2017) and campaign
GPS data (Amin et al. 1993) indicate $15 \mathrm{~mm} /$ year of right-lateral slip across the integrated Sumatran Fault Zone in South Sumatra. These rates suggest that we should expect more frequent large strike-slip earthquakes in this region than have been suggested by previous studies.

\begin{abstract}
Abbreviations
Cal Yr BP: calendar year before 'Present' (i.e. means before 1950); AD: anno domini (latin), means year of our Lord referring to the year of Christ's birth; Ma: million years ago; Kya: kilo year, means 1000-year unit; Km: kilometer; m: meter; K-Ar: kalium-Argon; AMS: accelerator mass spectrometry; SHCAL13: southern hemisphere calibration curve of Hoggs et al (2013); EPMA: electron probe microanalyzer; Fig: figure.
\end{abstract}

\section{Authors' contributions}

$\mathrm{DHN}$ is the first author who organized and conducted field works and studio analysis and developed the manuscript. KEB conducted petrology and chemical analysis of the Ranau Tuff, and he also revised the content and rewrote the manuscript. MRD conducted fieldwork together with DHN and helped with sampling, analysis of data, and contributed in developing manuscript. SA conducted fieldwork independently and contributed in developing the manuscript. SA also helped with organizing samples of Ranau Tuff and involved in laboratory analysis together with KEB and JSH. JSH is primarily responsible for conducting chemical analysis of the Ranau Tuff. All authors read and approved the final manuscript.

\section{Author details}

1 Research Center for Geotechnology, Indonesian Institute of Geosciences, Bandung, Indonesia. ${ }^{2}$ Earth Observatory of Singapore, Nanyang Technological University, Singapore, Singapore. ${ }^{3}$ Facility for Analysis Characterisation Testing Simulation, School of Materials, Science and Engineering, Nanyang Technological University, Singapore, Singapore.

\section{Ackowledgements}

This work is part of RC Geotechnology LIPI and the GREAT-ITB program in active fault studies, and also as a part of collaborative research between LIPI and EOS-NTU. We thank LAPI ITB and the POSCO hydropower electric plant project in the Semangko River area for facilitating fieldwork and giving access to the site, and for providing the high-resolution topography from a local site survey. We also thank Wisnu S. Priyanto for collecting additional Ranau Tuff samples.

14 March 2017, On behalf of all authors, Danny Hilman Natawidjaja.

\section{Competing interests}

We declare here that none of the authors have any competing interest in this publication, and all authors have approved the manuscript for submission to Geoscience Letter.

We also declare that none of the content of the manuscript has been published or submitted for any other publication.

\section{Consent for publication}

Not applicable.

Ethics approval and consent to participate

Not applicable.

\section{Funding}

Fieldwork was supported by annual research budget of RC Geotechnology LIPI and LAPI ITB. Chemical Laboratory analysis was supported by Earth Observatory of Singapore, NTU. Cost for publications was supported by AOGS Grant \# TC0131623.

\section{Publisher's Note}

Springer Nature remains neutral with regard to jurisdictional claims in published maps and institutional affiliations. 
Received: 20 March 2017 Accepted: 31 August 2017

Published online: 12 September 2017

\section{References}

Alloway BV, Pribadi A, Westgate JA, Bird M, Fifield LK, Hogg A, Smith I (2004) Correspondence between glass-FT and $14 \mathrm{C}$ ages of silicic pyroclastic flow deposits sourced from Maninjau caldera, west-central Sumatra. Earth Planet Sci Lett 227(1):121-133

Amin TC, Santosa S, Gunawan W (1993) Geological map of the Kotaagung quadrangle. Geological Agency, Ministry of Mine and Energy, Sumatera

Baroux E, Avouac J, Bellier O, Sebrier M (1998) Slip-partitioning and fore-arc deformation at the Sunda Trench, Indonesia. Terra Nova 10:139-144

Bellier O, Sebrier M (1994) Relationship between tectonism and volcanism along the Great Sumatran Fault Zone deduced by SPOT image analyses. Tectonophysics 233:215-231

Bellier O, Sebrier M (1995) Is the slip rate variation on the Great Sumatran Fault accommodated by fore-arc stretching? Geophys Res Lett 22(15):1969-1972

Bellier O, Bellon H, Sebrier M, Maury RC (1999) K-Ar age of the Ranau Tuffs: implications for the Ranau caldera emplacement and slip-partitioning in Sumatra (Indonesia). Tectonophysics 312:347-359

Berlage HPJ (1934) De aardbeving in zuid Sumatra van 25 Juni 1933: waarremingen in het epicentrale gebied. Nat Tijdschr Ned Ind 94:15-36

Bradley K, Feng L, Hill EM, Natawidjaja DH, Sieh K (2017) Implications of the diffuse deformations of the Indian Ocean lithosphere for slip partitioning of oblique plate convergence in Sumatra. J Geophys Res Solid Earth 122:572-591

Chesner CA, Rose WI, Deino A, Drake R, Westgate JA (1991) Eruptive history of Earth's largest Quaternary caldera (Toba, Indonesia) clarified. Geology 19:200-203

Curray J, Moore D, Lawver L, Emmel F, Raitt R, Henry M, Kieckhefer R (1979) Tectonics of the Andaman Sea and Burma. Am Assoc Pet Geol Mem 29:189-198

Donovan JJ, Tingle TN (1996) An improved mean number correction for quantitative microanalysis. J Microsc 2(1):1-7

Gafoer S, Cobrie T, Purnomo J (1986) Geologic map of the Lahat Quadrangle. Geol Res Dev Centre, South Sumatra

Gafoer S, Amin TC, Pardede R (1993) Geologi lembar Baturaja. Badan Geologi, ESDM, Sumatera

Hochstein MP, Sudarman S (1993) Geothermal Resourc Sumatra. Geothermics 22:181-200
Hogg AG, Hua Q, Blackwell PG, Niu M (2013) SHCAL13 southern hemisphere calibration, 0-50,000 years cal BP. Radiocarbon 55(4):1889-1903

McCaffrey R (1991) Slip vectors and stretching of the Sumatran fore arc. Geology 19:881-884

McCarthy AJ, Elders CF (1997) Cenozoic deformation in Sumatra: oblique subduction and the development of the Sumatran Fault System. Geol Soc Lond Spec Publ 126:355-363

Natawidjaja DH (1994) Quantitative geological assessments of Liwa earthquake 1994. In: Proceeding of Annual Convention of Indonesian Association of Geophysicists (HAGl) 1994

Natawidjaja DH, Triyoso W (2007) The Sumatran Fault Zone: from source to hazards. J Earthquake Tsunami 1(1):21-47

Owens PN, Walling DE, Leeks GJL (1999) Deposition and storage of finegrained sediment within the maain channel system of the river tweed, Scotland. Earth Surf Proc Land 24:1061-1076

Salisbury MJ, Patton JR, Kent AJ, Goldfinger C, Djajadihardja Y, Hanifa U (2012) Deep-sea ash layers reveal evidence for large, late Pleistocene and Holocene explosive activity from Sumatra, Indonesia. J Volcanol Geoth Res 231-232:61-71

Sieh K, Natawidjaja D (2000) Neotectonics of the Sumatran Fault, Indonesia. J Geophys Res 105(B12):28295-28326

Sieh K, Rais J, Bock Y (1991) Neotectonic and paleoseismic studies in West and North Sumatra. AGU 1991 Fall Meet Progr Abstacts 72(44):460

Sieh K, Zachariasen J, Bock Y, Edwards L, Taylor F, Gans P (1994) Active tectonics of Sumatra. Geo. Soc Amer Bull 26:382

Stehn CE (1934) Explosionen des Pematang Bata in der Suoh-senke (sud Sumatra) im jahre 1933. Natuurk Tijdschr v Ned Ind 94:46-68

Susilohadi S, Gaedicke C, Djajadihardja Y (2009) Structures and sedimentary deposition in the Sunda Strait, Indonesia. Tectonophysics 467:55-71

Talma AS, Vogel JC (1993) A simplified approach to calibrating 14 C dates. Radiocarbon 35(2):317-322

USGS (2015) Shuttle Radar Topographic Mission (SRTM) 1 Arc-second, United States Geological Survey

Westerveld J (1952) Quaternary volcanism on Sumatra. Geol Soc Am Bull 63:561-594

Westgate JA, Sandhu AS, Shane P (1997) Fission-track dating. In: Aitken M, Taylor RE (eds) Chronometric and Allied Dating in Archaeology. Plenum Publishing Corporation, New York

Widiwijayanti C, Deverchere J, Louat R, Harjono H, Diament M, Hidayat D (1996) Aftershock sequence of the 1994, Mw 6.8, Liwa earthquake, Indonesia: seismic rupture process in a volcanic arc. Geophys Res Lett 23:3051-3054

\section{Submit your manuscript to a SpringerOpen ${ }^{\circ}$ journal and benefit from:}

- Convenient online submission

- Rigorous peer review

- Open access: articles freely available online

- High visibility within the field

Retaining the copyright to your article

Submit your next manuscript at springeropen.com 